\title{
Computer Aided Vertically Integration of Radiology in Medical School Curriculum
}

\author{
Kartik Aggarwal $^{1 *}$ and Sunil Aggarwal ${ }^{2}$ \\ ${ }^{1}$ BMCC, New York, USA \\ ${ }^{2}$ Consultant radiologist, All Saints University School of Medicine, USA
}

Submission: August 11, 2017; Published: August 18, 2017

*Correspondence Address: Kartik Aggarwal, BMCC, New York, USA, Email: racer.kar@gmail.com

\begin{abstract}
The ever-growing technology and innovations in radiology justify the quest of radiology as a vertically integrated basic medical education curriculum from pre -clinical to clinical years. Computer assisted diagnosis and teaching is an integral part of education. Radiology is fundamental to understanding patient management and diagnosis. The importance of radiology and imaging research is itself a career for medical professionals. Though much has been talked about vertical integration or problem based learning in a medical curriculum, starting from semester one until graduation, it is still seen to be in infant stage in most medical schools in the Caribbean and across the globe. Some of the medical schools, like Al-Baha University, University of British Columbia, Sydney University and Australian National University, Canberra, that have vertically integrated radiology in pre-clinical to clinical years, have experienced much better student knowledge and understanding $[1,2]$.
\end{abstract}

Keywords: Radiology, vertical integration, medical curriculum

\section{Introduction}

Incorporating imaging in conventional anatomy teaching has been around with most medical schools in USA but vertical integration of radiology is still a far-fetched reality with only $5 \%$ medical schools have them in their undergraduate curriculum [3] and only $15 \%$ in UK [4]. This may cause inadequate learning outcome for the future physicians, and the use of computers assisted radiology. In a seemingly over -burdened undergraduate medical curriculum, radiology teaching through computers is now more important than ever, for the new medical graduates to know what and how to order to a radiology department for good patient management.

\section{Vertical Integrating Strategy Methodology}

Chairs of Radiology, pathology, anatomy and physics are important professionals to incorporate a vertically integrated curriculum of radiology. All other departments contribute to its development. We proposed a mix of various approaches that could be used to get a final outcome.

Kern et al. [5] six step approach was the first approach to get maximum inputs:

Step 1: Problem identification
Step 2: Educational need assessment

Step 3: Goals and objectives

Step 4: Educational strategies

Step 5: Implementation

Step 6: Evaluation and feedback

A wise man approach Laidlaw et al. (1995) was used as the filter approach to get eventual result into the final possible curriculum development from senior physicians and senior academicians.

\section{Results}

The six steps were studies by a committee so formed to integrate radiology, in conjunction with curriculum development committee.

\section{Step 1: Problem Identification}

Learning radiology has never been a traditional undergraduate integrated curriculum considering the "accelerated" medical curriculum falling short of time. This has led to deficiencies in overall student learning in terms of 


\section{Cancer Therapy \& Oncology International Journal}

computer assisted teaching and other instructional methods such as podcast, internet and presentations.

\section{Step 2: Educational Need Assessment}

Learning objectives based on development of a focused curriculum that could be vertically integrated will be the key factor in development of educational need [6].

\section{Step 3: Goals and Objectives}

The ultimate goal is to make the medical student with fundamental competency geared towards a comprehensive national board exam and residency. This will form the stepping stone for a radiology residency, as well.

\section{Step 4: Educational Strategies}

The approach towards comprehensive educational strategies will be to include radiology in the first four semesters of medical curriculum after a basic science or pre- medical courses knowledge.

Next, is the integration of radiology in higher semesters to become familiar with all the modalities of imaging including PACs and computer aided radiology? Use of class room lectures, seminars, radiology images banks and problem based learning could be used as a few teaching methods.

\section{Step 5: Implementation}

With the assistance of a dedicated faculty, the various imaging machines, like Ultrasound, X-rays, and CT scan need to be incorporated in a computerized radiology lab. MRI or nuclear imaging teaching can be introduced at the present facility, based on the budget, or a second radiology site with these facilities could be made use of.

\section{Step 6: Evaluation and Feedback}

Evaluation through program survey and student satisfactory performance will be done and this would be based on the weekly quizzes and end of the term exam in radiology. Need to further improve the course will be learnt for future implementation.

\section{Conclusion}

The need for vertical integration of radiology is evident from students demand for better understanding of medicine. Patient management requires the use of effective radiology [7]. Use of computers has become fundamental and so is PACS. Radiology needs to be integrated into medical curriculum and not as just "some X-rays "for it be a real learning tool for the medical students. Kern approach can be used as the basic guide to incorporate the entire needs fundamental to integrating radiology.

\section{References}

1. Lee JS, Aldrich JE, Eftekhari, A, Nicolaou S, Muller NL (2007) Implementation of a New Undergraduate Radiology Curriculum: Experience at the University of British Columbia. Canadian Association of Radiologists Journal 58 (5): 272-278.

2. Al Qahtani F, Abdelaziz A (2014) Integrating radiology vertically into an undergraduate medical education curriculum: a triphasic integration approach. Advances in Medical Education and Practice 5: 185-189.

3. Waterston SW, Stewart IJ (2005) Survey of clinician's attitudes to the anatomical teaching and knowledge of medical students. Clinical Anatomy 18(5): 380-384.

4. Bhogal P, Booth TC, Phillips AJ, Golding (2012) Radiology in the undergraduate medical curriculum - Who, how, what and where? Clinical Radiology 67(12): 1146-1152.

5. Kern DE, Thomas PA, Howard DM, Bass EB (1998) Baltimore: Johns Hopkins Univ Pr, Maryland, USA, pp. 178.

6. Harden RM (2000) The integration ladder: a tool for curriculum planning and evaluation. Medical Education 34(7): 551-557.

7. Sunil Aggarwal, Sanju A, Somya A (2016) Pixel/Voxel-Based Machine Learning (PML) and Big Data in Medical Imaging: Detection and Regulation. Canc Therapy \& Oncol Int J 2(4): 555593.

Your next submission with Juniper Publishers will reach you the below assets

- Quality Editorial service

- Swift Peer Review

- Reprints availability

- E-prints Service

- Manuscript Podcast for convenient understanding

- Global attainment for your research

- Manuscript accessibility in different formats

( Pdf, E-pub, Full Text, Audio)

- Unceasing customer service

Track the below URL for one-step submission https://juniperpublishers.com/online-submission.php 